\title{
Leaf nitrogen thresholds ensuring high antioxidant features of Vaccinium corymbosum cultivars
}

\author{
E. Yañez-Mansilla ${ }^{1}$, P. Cartes ${ }^{2,4}$, M. Reyes-Díaz ${ }^{2,4}$, A. Ribera-Fonseca ${ }^{3,4}$, Z. Rengel ${ }^{5}$, W. \\ $\operatorname{Lobos}^{3}$, M. Alberdi ${ }^{2,4 *}$
}

${ }^{1}$ Doctoral Program in Sciences of Natural Resources, Universidad de La Frontera, Temuco, Chile. ${ }^{2}$ Departamento de Ciencias Químicas y Recursos Naturales; Facultad de Ingeniería y Ciencias, Universidad de La Frontera. ${ }^{3}$ Departamento de Producción Agropecuaria, Facultad de Ciencias Agropecuarias y Forestales, Universidad de La Frontera, Temuco, Chile. ${ }^{4}$ Center of Plant-Soil Interaction and Natural Resources Biotechnology, Scientific and Technological Bioresource Nucleus (BIOREN), Universidad de La Frontera. ${ }^{5}$ Soil Science and Plant Nutrition, School of Earth and Environment, The University of Western Australia, Crawley, WA 6009, Australia. ${ }^{*}$ Corresponding author:miren.alberdi@ufrontera.cl

\begin{abstract}
Deficiency or excess of nitrogen $(\mathrm{N})$ supply can promote formation of reactive oxygen species in plants, inducing oxidative stress. Otherwise, plants may enhance phenolics biosynthesis and antioxidant capacity under $\mathrm{N}$ deficiency, but this effect is plant species-dependent. There is no information about influence on phenolics and antioxidant activity in highbush blueberry (Vaccinium corymbosum L.), in which quality and commercial importance depend on high phenolics concentration. We studied the effect of variable $\mathrm{N}$ supply (0 to $38 \mathrm{mM}$ ) on $\mathrm{N}$ uptake and antioxidant responses in two highbush blueberry cultivars (Legacy and Bluegold) hydroponically grown at the long-term. Nitrogen leaves concentration was enhanced for both cultivars at increasing $\mathrm{N}$ supply. Bluegold decreased $\mathrm{CO}_{2}$ assimilation at $0 \mathrm{~N}$ treatment, possibly due to both, insufficient $\mathrm{N}$ concentration and a decline in superoxide dismutase (SOD) activity. In contrast, SOD was activated in Legacy at $0 \mathrm{~N}$, and interestingly only this cultivar maintained $\mathrm{CO}_{2}$ assimilation rates across all $\mathrm{N}$ treatments. Both cultivars showed higher phenolics and antioxidant activity levels at $9 \mathrm{mM}$. Despite the differential responses among the cultivars, we propose a threshold of $15 \mathrm{~g} \mathrm{~N} \mathrm{~kg}^{-1} \mathrm{DW}$ to ensure high antioxidant activity and quality in blueberry leaves.
\end{abstract}

Keywords: Antioxidant responses, phenolic compounds, photosynthesis, superoxide dismutase, Vaccinium corymbosum 


\section{Introduction}

Nitrogen (N) is an essential macronutrient for plant growth and development (Marschner, 1986). It is a constituent of the photosynthetic apparatus, enzymes, proteins and pigments. Nitrogen deficiency or excess can negatively influences the plant metabolism. Nitrogen deficient growth media results in decreased contents of photosynthetic pigments (chlorophyll and carotenoids), thereby reducing the photosynthetic performance (particularly $\mathrm{CO}_{2}$ assimilation) (Huang et al., 2004). A strategy in some plant species growing under $\mathrm{N}$ deprivation is to recycle $\mathrm{N}$ from amino acids and proteins for new tissue growth (Kováčik et al., 2007). By contrast, $\mathrm{N}$ toxicity is commonly associated with plant tissue ammonium $\left(\mathrm{NH}_{4}^{+}\right)$accumulation. Depletion of $\mathrm{C}$ compounds that serve as a substrate for amino acid production has been reported in Arabidopsis plants grown under excessive N supply (Hachiya et al., 2012).

Nitrogen deficiency or excess increase the production of reactive oxygen species (ROS) in plants, which results in lipid peroxidation of cell membranes (Asada et al., 1987). In order to alleviate the oxidative damage induced by $\mathrm{N}$-stress, enzymatic antioxidant systems such as superoxide dismutase (SOD) could be activated in plant tissues (Asada et al., 1987). Nevertheless, according to Huang et al. (2004), N deficiency may also reduce SOD activity, exacerbating lipid peroxidation in rice (Oryza sativa). Otherwise, non-enzymatic antioxidant compounds (e.g. phenolics) have been induced in N-starved plants, leading an enhancement of the antioxidant activity in mustard (Brassica juncea) (Li et al., 2008).

It is noteworthy that $\mathrm{N}$ supply may also impact the biosynthesis of some aromatic amino acids (Fritz et al., 2006) such as phenylalanine, tyrosine, and tryptophan, which are substrates for the synthesis of phenolic compounds, which can involved in antioxidant responses.
Hence, plants growing at a high $\mathrm{N}$ supply generally have decreased levels of phenolic compounds (Nybakken et al., 2013), and the $\mathrm{N}$ excess might be diverted into amino acid and protein synthesis. Conversely, N-deprived plants showed an increased C resources allocation towards phenolic compounds production (Bryant et al., 1983). Nevertheless, enhanced phenolics (e.g. anthocyanin) concentration in response to $\mathrm{N}$ supply has also been reported (Okamoto et al., 2003).

Therefore, to the date, the available literature is contradictory regarding $\mathrm{N}$ effects on phenolics accumulation and antioxidant capacity (Okamoto et al., 2003; Mogren et al., 2006). Even though most related reports have showed an inverse relationship between $\mathrm{N}$ availability and phenolics concentration in plant tissues, a decrease in $\mathrm{N}$ supply for improving antioxidant capacity could be used as a strategic tool to enhance both the quality and the profitability of some crops, minimizing environmental impact of $\mathrm{N}$ (Larbat et al., 2012).

Highbush blueberry (Vaccinium corymbosum L.) is an important crop in Southern Chile that contains high concentration of phenolic acids, flavonols and anthocyanins (Ribera et al., 2010; Ehlenfeldt et al., 2001), which exhibit noticeable antioxidant capacity.

Currently, $\mathrm{N}$ fertilization commonly applied as ammonium to blueberry orchard varies between 20 and $140 \mathrm{~kg} \mathrm{ha}^{-1}$ (Hanson, 2006). It has been reported that blueberry plants are sensitive to $\mathrm{N}$ excess and common values for leaf $\mathrm{N}$ concentration ranged from 15 to $21 \mathrm{~g} \mathrm{~kg}^{-1} \mathrm{DW}$ (Bañados et al., 2012).

Despite that in previous results we observed a differential response on physiological and antioxidant parameters to $\mathrm{N}$ fertilization during 4 days (Yañez-Mansilla $e t$ al., 2014), there are not studies about $\mathrm{N}$ concentration in leaves that maintain a high antioxidant performance 
in blueberries at the long-term. We hypothesized that there is $\mathrm{N}$ concentration threshold that ensure a high phenolic concentration and antioxidant capacity without detrimental effects on plant performance. It is also important to highlight that behind the beneficial effects of these compounds, their increase in vegetative tissues of the plant (eg. leaves) subsequently can determine the levels of its accumulation in fruits. The aim of this work was to evaluate $\mathrm{N}$ uptake and antioxidant responses in two highbush blueberry cultivars hydroponically grown under variable $\mathrm{N}$ levels at the long-term.

\section{Materials and Methods}

\subsection{Experimental conditions}

A nutrient solution assay was carried out during 4 weeks using two highbush blueberry ( $V$. corymbosum L.) cultivars (Legacy and Bluegold) with contrasting tolerance to abiotic stresses including aluminum (Al) and manganese (Mn) toxicities and high UV-B radiation (Reyes-Díaz et al., 2010; Rojas-Lillo et al., 2013). The choice of harvest time was made to evaluate long-term $\mathrm{N}$ effects in order to determine whether the responses obtained on the short-term (Yañez-Mansilla et al., 2014) are time-dependent. Two-year-old plants were provided by the commercial farm "Berries San Luis" located in Lautaro, Araucanía Region, Chile. During the time course of the experiment, greenhouse environmental conditions were: temperature $25 / 20{ }^{\circ} \mathrm{C}$ (day/night), photoperiod 16/8 h (light/dark) and 70\% relative humidity. Before beginning the assay, plants were conditioned during 72 hours in plastic boxes filled with $10 \mathrm{~L}$ of modified Hoagland solution (Hoagland and Arnon, 1950). After conditioning, plants were transferred to boxes filled with Hoagland solution without $\mathrm{N}$ for 72 hours.
Later on, plants were grown under the following $\mathrm{N}$ treatments: $0,9,18,28$ or $38 \mathrm{mM} \mathrm{N}$. The $\mathrm{N}$ treatments were applied based on differential $\mathrm{NH}_{4} \mathrm{NO}_{3}$ levels in the culture media, and they were chosen in order to exceed the $\mathrm{N}$ sufficiency level associated with adequate photosynthetic performance and plant growth at the short-term (Yañez-Mansilla et al., 2014). Nutrient solutions were replaced every 7 days and aerated during the course of experiment with an aquarium pump. The solution $\mathrm{pH}$ was adjusted to 4.8 daily using $0.1 \mathrm{M} \mathrm{HCl}$.

At the end of the experiment, in vivo carbon dioxide $\left(\mathrm{CO}_{2}\right)$ assimilation was measured as described below. In addition, at the end of the experiment, fully expanded leaves from the second node as well as roots were collected, snap-frozen in liquid $\mathrm{N}_{2}$ and then stored at $-20{ }^{\circ} \mathrm{C}$ for lipid peroxidation or at -80 ${ }^{\circ} \mathrm{C}$ for other biochemical analyses. Additional samples were dried for determining total tissue $\mathrm{N}$ concentration.

\subsection{Tissue $N$ concentration}

The $\mathrm{N}$ concentration in leaves and roots was analyzed by the Kjeldahl method as described by Sadzawka et al. (2004).

\section{3. $\mathrm{CO}_{2}$ assimilation measurements}

Carbon dioxide $\left(\mathrm{CO}_{2}\right)$ assimilation was measured (between 09:00 and 10:00 AM) in intact leaves attached to the second node using a portable photosynthesis system (LI-6400, LI-COR Bioscience, Inc., Lincoln, Nebraska, US \& Canada) provided by a leaf chamber with a controlled light source $(300 \mu \mathrm{mol}$ $\mathrm{m}^{-2} \mathrm{~s}^{-1}$ ) as described by Reyes-Díaz et al (2011). In the leaf chamber the reference $\mathrm{CO}_{2}$ concentration was $360 \mathrm{ppm}$, with a flow rate of $200 \mathrm{~mL} \mathrm{~min}^{-1}, 80 \%$ relative humidity and $20 \pm 2{ }^{\circ} \mathrm{C}$ temperature. 


\subsection{Lipid peroxidation assay}

Lipid peroxidation was assessed in frozen samples by monitoring the thiobarbituric acid reacting substances (TBARS) as an index of oxidative damage in plant cells. The absorbance was measured at 532, 600 and $440 \mathrm{~nm}$ in order to correct the interference generated by TBARS-sugar complexes according to the modified method (Du and Bramlage, 1992).

\subsection{Superoxide dismutase activity}

Frozen plant material was extracted with $50 \mathrm{mM}$ potassium phosphate buffer $\left(\mathrm{K}_{2} \mathrm{HPO}_{4}-\mathrm{KH}_{2} \mathrm{PO}_{4}\right)$, $\mathrm{pH}$ 7.0. Superoxide dismutase (SOD) (EC. 1.15.1.1) activity was analyzed by measuring the photochemical inhibition of nitroblue tetrazolium (NBT) at $560 \mathrm{~nm}$ (Giannopolis et al., 1977). One SOD unit was defined as the amount of enzyme that generates a 50\% inhibition of NBT reduction (Donahue et al., 1997). The enzyme activity was expressed on both fresh weight and protein basis. Protein in the crude enzyme extract was measured spectrophotometrically by the Bradford method (Bradford, 1976).

\subsection{Radical scavenging activity}

The radical scavenging activity (RSA) of roots and leaves was assayed by the free radical 2.1-diphenyl1-picrylhydrazyl (DPPH) scavenging method as described by Chinnici et al (2004). The absorbance was measured spectrophotometrically at $515 \mathrm{~nm}$ using Trolox as standard.

\subsection{Phenolic compound contents}

Total phenols were quantified in a spectrophotometer at $765 \mathrm{~nm}$ using the Folin-Ciocalteu method and chlorogenic acid as the standard (Slinkard and
Singleton, 1977). Total flavonoids were measured by the aluminum chloride colorimetric assay, using rutin as the standard (Cheng and Breen, 1991). Total anthocyanins were analyzed by the method described by Chang et al (2002). The absorbance of anthocyanin extracts was determined in a spectrophotometer at 530 and $657 \mathrm{~nm}$. Total anthocyanin content was expressed as $\mathrm{mg}$ of cyanidin-3-glucoside equivalent (c3g) per g FW.

\subsection{Statistical analyses}

The experiment was arranged in a completely randomized factorial design with two cultivars, five $\mathrm{N}$ treatments and three biological replicates. The effect of $\mathrm{N}$ on chemical and biochemical parameters was assessed by two-way ANOVA after the normality and homoscedasticity tests. Tukey's test was used to evaluate differences between means (at $P \leq 0.05$.) Additionally, Pearson's correlations were used to test the relationships between two response variables. Analyses were performed with Sigma Stat software v. 2.0 (SPSS, Chicago, IL).

\section{Results}

\subsection{Leaf nitrogen concentration}

In general, leaf $\mathrm{N}$ concentration was enhanced in both cultivars with an increase in $\mathrm{N}$ supply (Figure 1A). Blueberry leaves of both cultivars exhibited the lowest $\mathrm{N}$ concentration (around $10 \mathrm{~g} \mathrm{~N} \mathrm{~kg}^{-1} \mathrm{DW}$ ) under $\mathrm{N}$ deprivation $(P \leq 0.05)$, and $\mathrm{N}$ doses up to $18 \mathrm{mM}$ did not produce significant differences in leaf $\mathrm{N}$ concentration between the two cultivars. However, Bluegold had higher $\mathrm{N}$ concentration (21.5 $\left.\mathrm{g} \mathrm{N} \mathrm{kg}^{-1} \mathrm{DW}\right)$ than Legacy $\left(18.7 \mathrm{~g} \mathrm{~N} \mathrm{~kg}^{-1} \mathrm{DW}\right)$ at the $38 \mathrm{mM} \mathrm{N}$ treatment, and these values were about two-fold higher than those of $\mathrm{N}$-starved plants. 
Roots of untreated Legacy plants had 26\% less N than plants grown with 9 to $38 \mathrm{mM} \mathrm{N}$ (Figure 1B). For Bluegold, we did not detect significant differences in root $\mathrm{N}$ concentration (average of $8.5 \mathrm{~g} \mathrm{~N} \mathrm{~kg}^{-1}$ DW) at $\mathrm{N}$ doses up to $28 \mathrm{mM}$. Nevertheless, at the highest $\mathrm{N}$ supply, a significant increase in $\mathrm{N}$ concentration occurred in Bluegold roots. It is worth noting that Legacy roots had $\mathrm{N}$ concentration twice as high as the Bluegold $(P \leq 0.05)$ at $\mathrm{N}$ doses up to $28 \mathrm{mM}$.

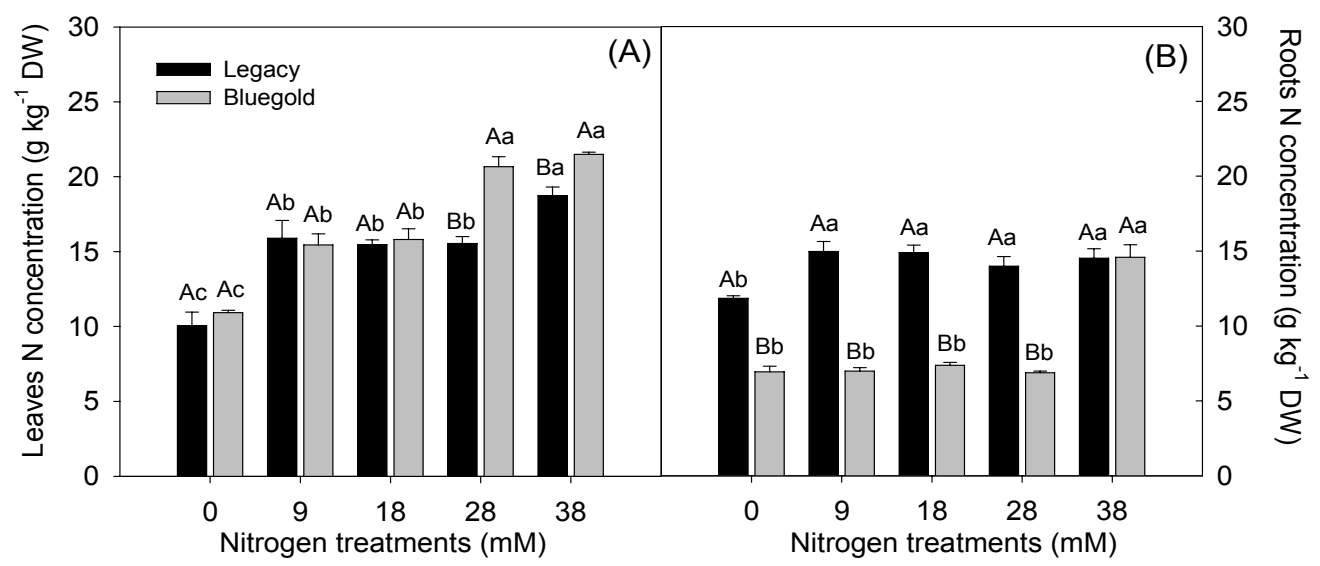

Figure 1. Nitrogen concentration in leaves (A) and roots (B) of two blueberry cultivars under different $\mathrm{N}$ treatments for 4 weeks. The values represent the average of three replicates $\pm \mathrm{SE}$. Different lowercase letters indicate statistically significant differences among $\mathrm{N}$ treatments for the same cultivar. Different uppercase letters indicate differences between cultivars for the same $\mathrm{N}$ treatment.

\subsection{Carbon dioxide assimilation}

No differences in $\mathrm{CO}_{2}$ assimilation were found in Legacy leaves as a result of variable $\mathrm{N}$ supply for 4 weeks (Figure 2). Comparatively, when no $\mathrm{N}$ was applied, $\mathrm{CO}_{2}$ assimilation in Bluegold was about $20 \%$ lower than that of $\mathrm{N}$-treated plants $(P \leq 0.05)$.

\subsection{Lipid peroxidation}

In the leaves of both cultivars, lipid peroxidation was approximately $50 \%$ lower $(P \leq 0.05)$ in N-treated plants compared with those untreated (Figure $3 \mathrm{~A}$ ).
Then, there was an inverse significant correlation between $\mathrm{N}$ concentration and lipid peroxidation for Legacy and Bluegold leaves ( $\mathrm{r}=-0.809, p \leq 0.05 ; \mathrm{r}$ $=-0.509, P \leq 0.05$, respectively). At all $\mathrm{N}$ treatments roots of both cultivars showed less lipid peroxidation compared to leaves (Figure 3B). Furthermore, 28 or $38 \mathrm{mM} \mathrm{N}$ in Legacy reduced lipid peroxidation by at least $50 \%$ in comparison with other $\mathrm{N}$ supplies. 


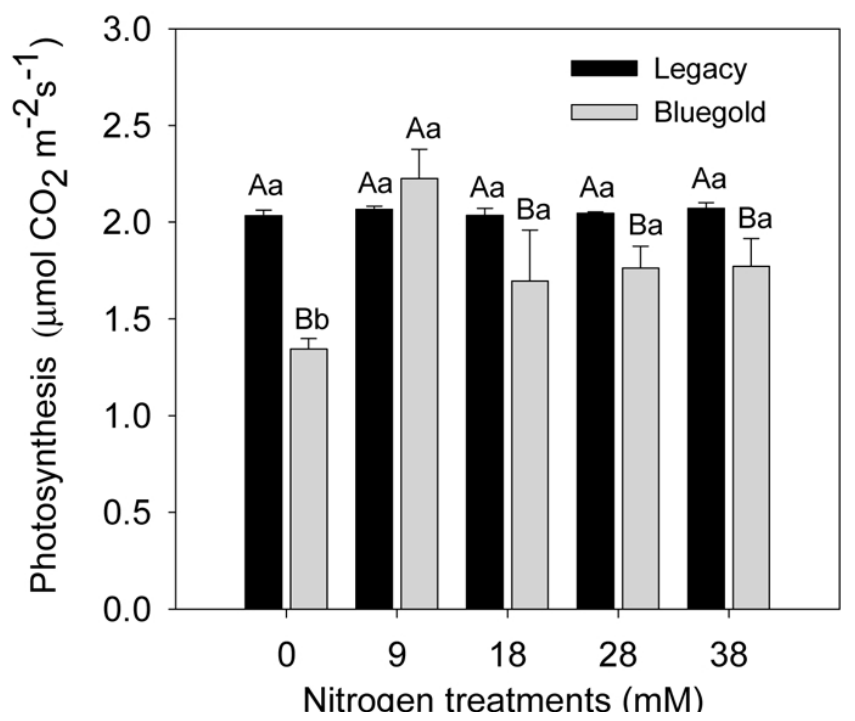

Figure 2. Nitrogen effects on $\mathrm{CO}_{2}$ assimilation of two cultivars of highbush blueberries for 4 weeks. The values represent the average of three replicates \pm SE. Different lowercase letters indicate statistically significant differences among $\mathrm{N}$ treatments for the same cultivar. Different uppercase letters indicate differences between cultivars for the same $\mathrm{N}$ treatment.

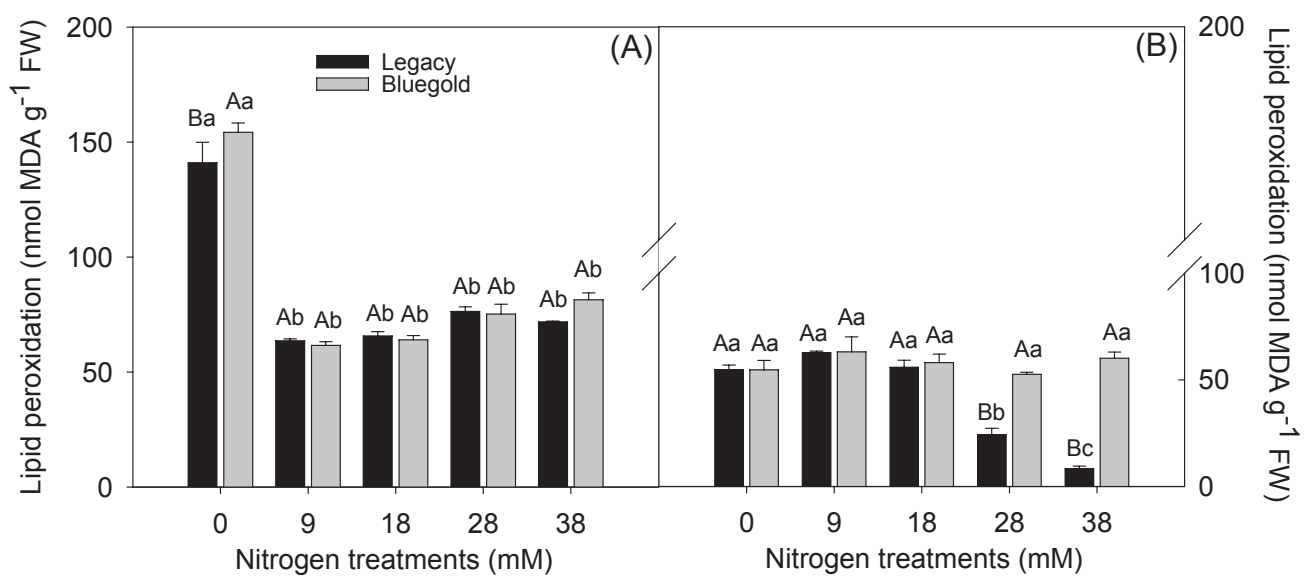

Figure 3. Lipid peroxidation in leaves (A) and roots (B) of two blueberry cultivars under different $\mathrm{N}$ treatments for 4 weeks. The values represent the average of three replicates \pm SE. Different lowercase letters indicate statistically significant differences among $\mathrm{N}$ treatments for the same cultivar. Different uppercase letters indicate differences between cultivars for the same $\mathrm{N}$ treatment. 


\subsection{Radical scavenging activity}

In both cultivars, no differences were found in the radical scavenging activity (RSA) of leaves at all $\mathrm{N}$ treatments (Figure 4A). However, at $\mathrm{N}$ supply above
$18 \mathrm{mM}$, leaf RSA was higher in Bluegold than Legacy (Figure 4A). In roots of both cultivars, we observed a trend of decreasing RSA in treatments up to $18 \mathrm{mM} \mathrm{N}$, followed by significantly increased RSA at 28 and $38 \mathrm{mM} \mathrm{N}$ (Figure 4B).

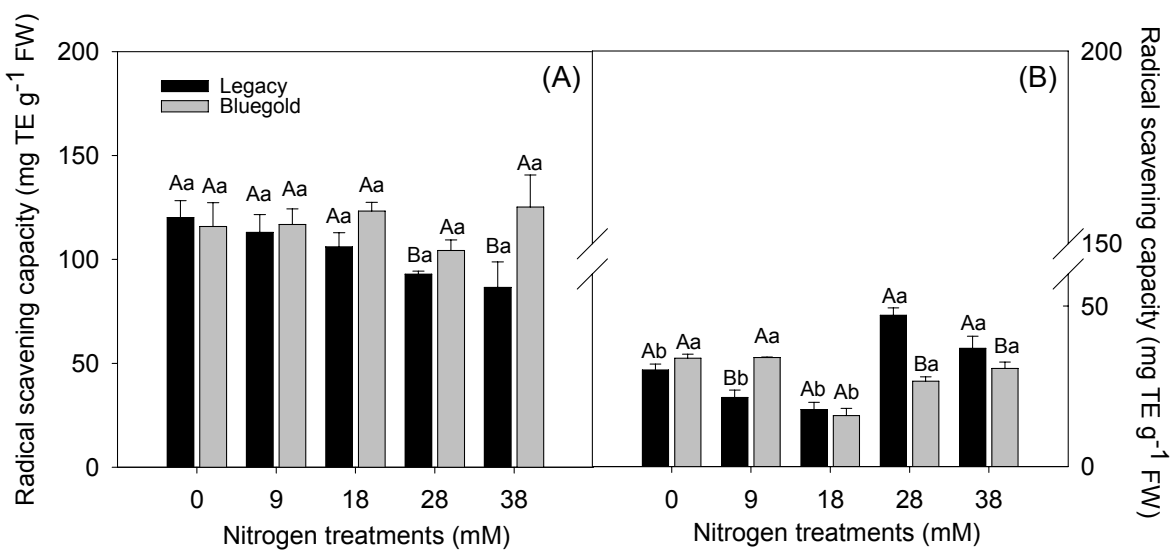

Figure 4. Antioxidant activity in leaves (A) and roots (B) of two blueberry cultivars under different $\mathrm{N}$ treatments for 4 weeks. The values represent the average of three replicates \pm SE. Different lowercase letters indicate statistically significant differences among $\mathrm{N}$ treatments for the same cultivar. Different uppercase letters indicate differences between cultivars for the same $\mathrm{N}$ treatment.

\subsection{Total phenolics, flavonoids and anthocyanins con- centrations}

Total phenolics concentration in Legacy leaves did not vary when plants were cultivated at $\mathrm{N}$ doses up to 18 $\mathrm{mM}$. However, phenolics concentration decreased significantly $(P \leq 0.05)$ at 28 and $38 \mathrm{mM} \mathrm{N}$ (Figure 5A). Thus, a $49 \%$ decrease in the concentration of total phenolics was found at $38 \mathrm{mM} \mathrm{N}$ compared to the levels found in $0 \mathrm{~N}$ treated plants. Likewise, a reduction of at least $25 \%$ in total phenolics concentration was observed in Bluegold leaves as a consequence of $\mathrm{N}$ supply above $18 \mathrm{mM}$. There was an inverse correlation between leaf concentration of $\mathrm{N}$ and phenolics in each cultivar (Legacy: $\mathrm{r}=-0.569, P \leq$ 0.05; Bluegold: $\mathrm{r}=-0.697, P \leq 0.05$ ). In general, Legacy accumulated more phenols than Bluegold in roots, and the lowest concentration was observed at 18 and $28 \mathrm{mM}$ $\mathrm{N}$ in both cultivars (Figure 5B). No significant effect of $\mathrm{N}$ on flavonoids was observed in Legacy (Figure 5C). In Bluegold a significant increase of these compounds was found due to $\mathrm{N}$ supply. In roots of both cultivars, flavonoid concentration nearly doubled at $9 \mathrm{mM} \mathrm{N}$ compared to $\mathrm{N}$ starved plants, staying relatively constant with a further increase in the N supply (Figure 5D). Total concentration of anthocyanin in leaves steadily decreased with increasing $\mathrm{N}$ doses in both cultivars (Figure 6). Therefore, an inverse correlation occurred between anthocyanin and $\mathrm{N}$ concentrations in leaves of Legacy and Bluegold ( $\mathrm{r}=-0.811, P \leq 0.05 ; \mathrm{r}=-0.742, P \leq 0.05$, respectively). 


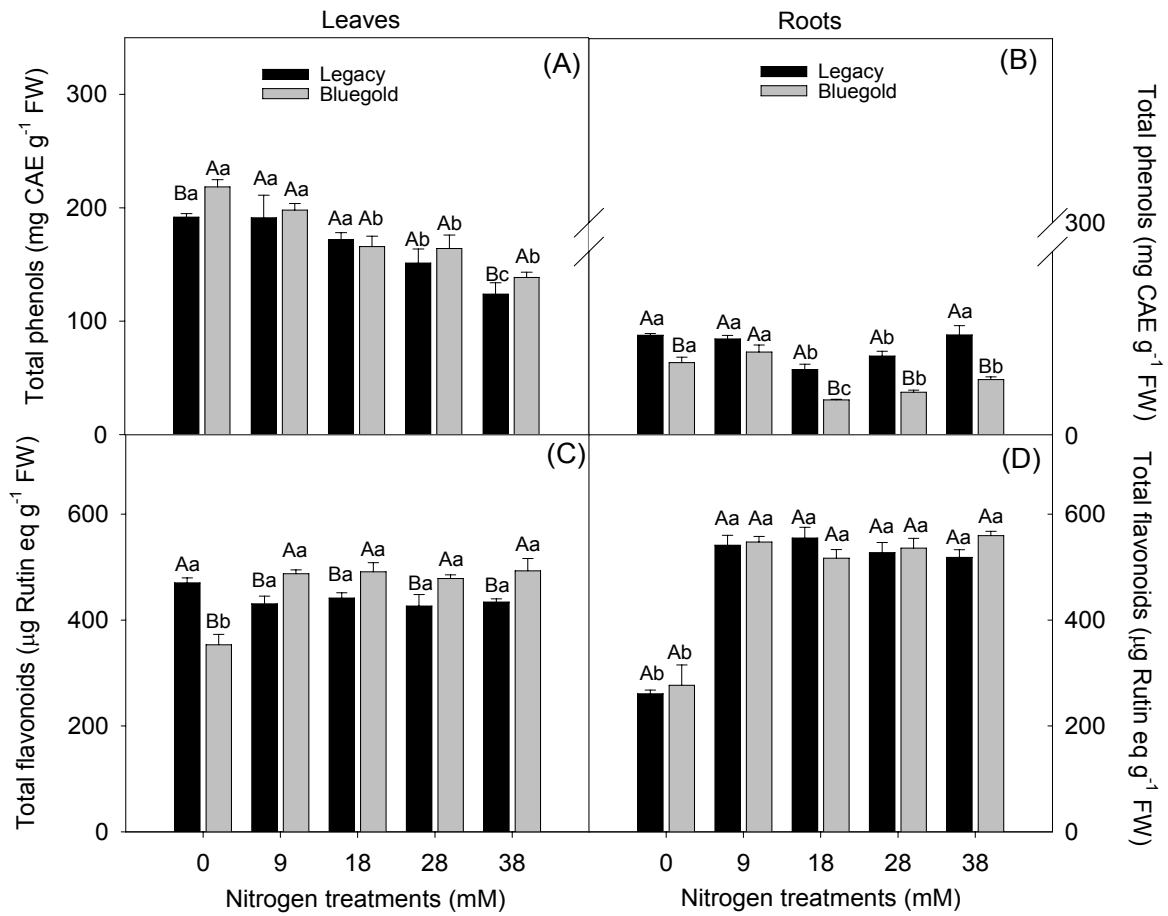

Figure 5. Total phenols $(A, B)$ and flavonoids $(C, D)$ of two blueberry cultivars under different $\mathrm{N}$ treatments for 4 weeks. The values represent the average of three replicates $\pm \mathrm{SE}$. Different lowercase letters indicate statistically significant differences among $\mathrm{N}$ treatments for the same cultivar. Different uppercase letters indicate differences between cultivars for the same $\mathrm{N}$ treatment.

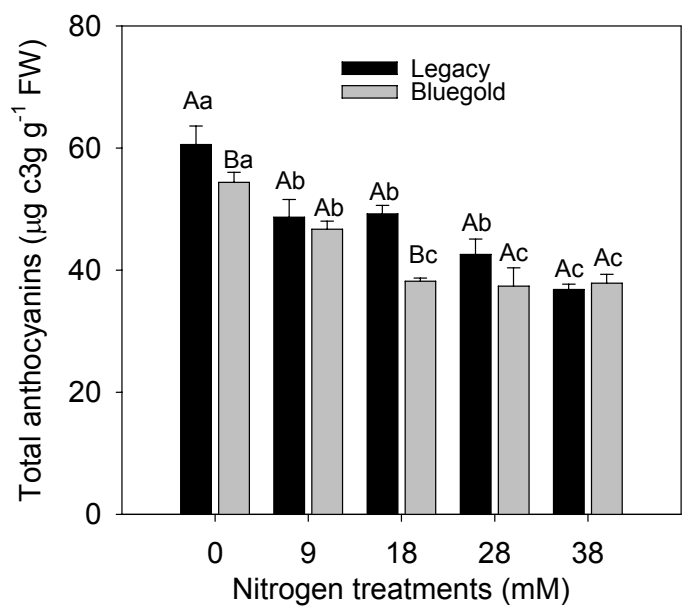

Figure 6. Total anthocyanins in leaves of two blueberry cultivars under different $\mathrm{N}$ treatments for 4 weeks. The values represent the average of three replicates \pm SE. Different lowercase letters indicate statistically significant differences among $\mathrm{N}$ treatments for the same cultivar. Different uppercase letters indicate differences between cultivars for the same $\mathrm{N}$ treatment. 


\subsection{Superoxide dismutase activity}

In leaves and roots, similar trend in SOD activity was found on protein and fresh weight basis in both cultivars (Figure 7A-D). The highest specific SOD activity was observed at 0 and $38 \mathrm{mM} \mathrm{N}$ in leaves of Legacy and Bluegold, respectively (Figure 7A).
The roots of both cultivars showed less SOD activity than leaves across $\mathrm{N}$ treatments (Figure 7B,D). In Bluegold roots, $\mathrm{N}$ application did not influence SOD activity, whereas in Legacy there was a strong decrease $(P \leq 0.05)$ in the enzyme activity in treatments from $18 \mathrm{mM} \mathrm{N}$ (Figure 7B).

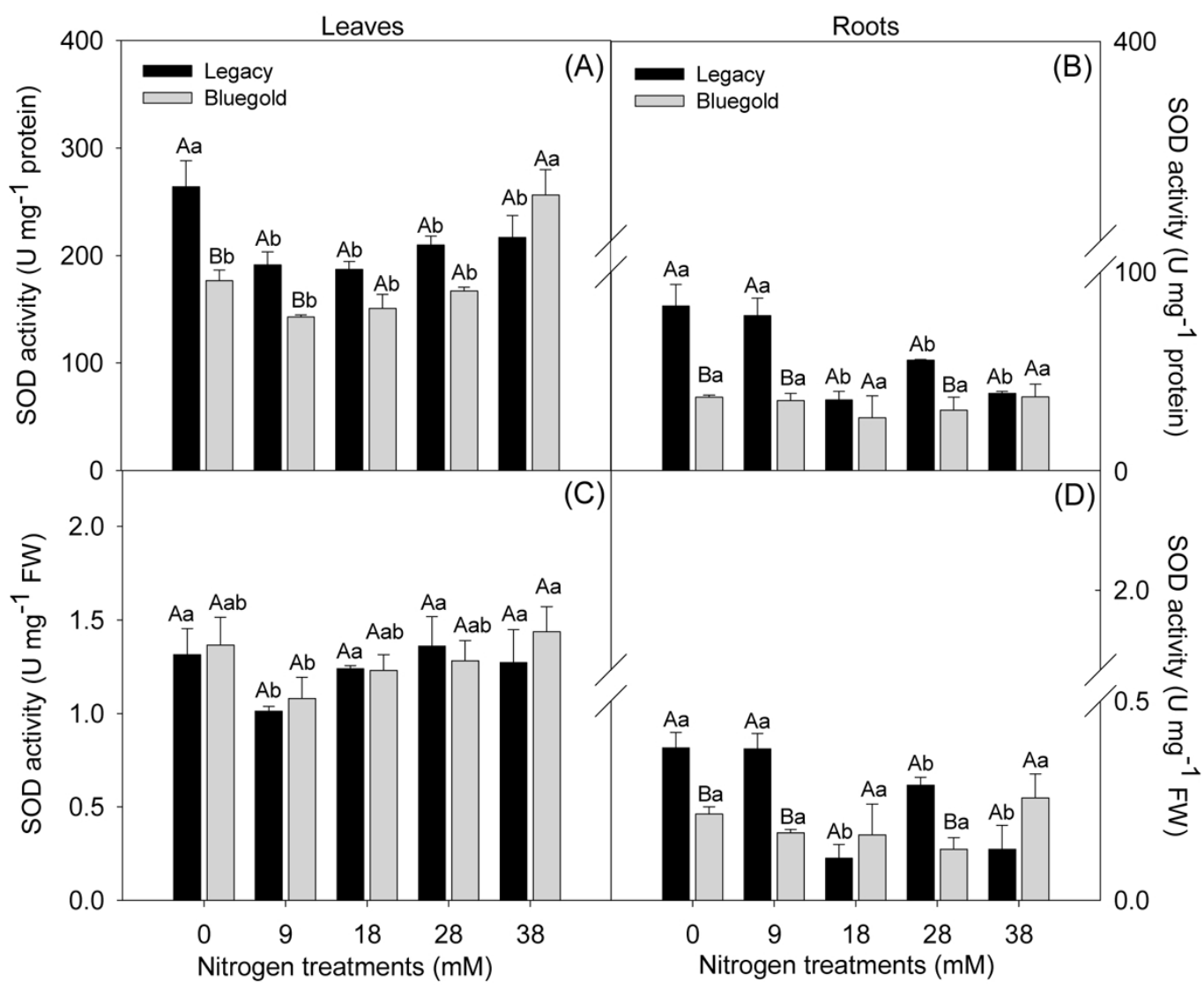

Figure 7. SOD specific activity $(A, B)$ and fresh weight $(C, D)$ of two blueberry cultivars under different $\mathrm{N}$ treatments for 4 weeks. The values represent the average of three replicates \pm SE. Different lowercase letters indicate statistically significant differences among $\mathrm{N}$ treatments for the same cultivar. Different uppercase letters indicate differences between cultivars for the same $\mathrm{N}$ treatment. 


\section{Discussion}

Blueberry leaves has been well characterized for its high antioxidant value. However, to our knowledge, there are no reports about the optimal fertilization strategies that could maximize its antioxidant richness, especially in terms of $\mathrm{N}$ nutrition. Controversial results regarding $\mathrm{N}$ fertilization effects on phenolics accumulation and antioxidant capacity in plants have been previously reported (Okamoto et al., 2003; Mogren et al., 2006). Nevertheless, it might be expected that a range of $\mathrm{N}$ concentrations in blueberry plant tissues could induce phenylpropanoid pathway and thus enhance phenolics synthesis, without deleterious effects on plant production.

Our results showed differences in physiological and biochemical features between cultivars Bluegold and Legacy as a consequence of increasing $\mathrm{N}$ supply at 4 weeks. Consistent with earlier studies (Bañados et al., 2012), we found that leaves $\mathrm{N}$ concentration steadily rose at increasing $\mathrm{N}$ supply in both cultivars (Figure 1). It has been reported that wheat cultivars could exhibit differential N uptake (Diekmann and Fischbeck, 2005). In this context, we observed that Legacy had nearly 2-fold higher $\mathrm{N}$ concentration than Bluegold under $\mathrm{N}$ treatments, but only in roots (Figure 1B), without important variation in leaf $\mathrm{N}$ between the cultivars up to $18 \mathrm{mM} \mathrm{N}$. In general, the leaf $\mathrm{N}$ concentrations obtained in this study (from 10 to $21 \mathrm{~g} \mathrm{~N} \mathrm{~kg}^{-1}$ DW) were within the range of those found by Bañados et al. (2012).

Even though it is widely recognized that $\mathrm{N}$ nutrition may positively influence the photosynthetic performance of plants (Agüera et al., 2010), in our study we did not detect any difference in $\mathrm{CO}_{2}$ assimilation regardless of the $\mathrm{N}$ supply in Legacy (Figure 2). In contrast, Bluegold showed a significant decline in photosynthesis, but only when plants grown under $\mathrm{N}$ starvation (Figure 2), indicating that this cultivar seems to be sensitive to low leaf $\mathrm{N}$ concentration (10 $\left.\mathrm{g} \mathrm{kg}^{-1} \mathrm{DW}\right)$. Nevertheless, our previous results showed a differential responses under $\mathrm{N}$ starvation or excess during 4 days exposure to differential $\mathrm{N}$ supply (Yañez-Mansilla et al., 2014), suggesting that acclimation to differential $\mathrm{N}$ supply can occur over time. Our earlier studies on aluminum (Al) toxicity in cultivars of highbush blueberry showed that Legacy and Bluegold were Al-resistant and Al-sensitive, respectively (Reyes-Díaz et al., 2010). These differences were explained mainly by the differential antioxidant capacity, which was higher in Legacy than Bluegold. Thus, we expected that those cultivars might also differ in their ability to tolerate $\mathrm{N}$ deficiency or excess. Previous studies indicated that young blueberry plants are sensitive to $\mathrm{N}$ excess, causing decreased growth and leaf chlorosis (Bañados et al., 2012). In contrast, rice plants were sensitive to $\mathrm{N}$ deprivation, exhibiting a significant reduction in net photosynthesis accompanied by an increase in ROS production and lipid peroxidation (Huang et al., 2004). In our experiment, symptoms of $\mathrm{N}$ toxicity in leaves and roots were not observed. However, $\mathrm{N}$ starvation led to the lowest leaf $\mathrm{N}$ concentration (10 $\mathrm{g} \mathrm{kg}^{-1} \mathrm{DW}$, Figure $\left.1 \mathrm{~A}\right)$, which was associated with the highest lipid peroxidation in this tissue, without difference between the cultivars (Figure 3A). Indeed, $\mathrm{N}$ addition significantly reduced lipid peroxidation in leaves of both cultivars, without difference among $\mathrm{N}$ supply doses. This result was also detected at root level, but only in Legacy.

A decline in concentration of some antioxidant compounds occurred in spinach plants cultivated under $\mathrm{N}$ starvation (Logan et al., 1999). Despite these findings, in our study leaf radical scavenging activity (RSA) of both cultivars did not change with variable $\mathrm{N}$ supply (Figure 4A). Legacy roots showed increased antioxidant capacity at the higher $\mathrm{N}$ addition level (Figure 4B). It may be that $\mathrm{N}$ concentration in roots up to 14 $\mathrm{g} \mathrm{kg}^{-1}$ DW could increase accumulation of the anti- 
oxidant compounds in this cultivar. In fact, this response could be partially explained by enhanced total flavonoid concentrations (Figure 5D). This increase in antioxidant capacity and flavonoids in roots was associated with decreased lipid peroxidation at the higher $\mathrm{N}$ doses, but only in Legacy (Figure 3B).

The $\mathrm{N}$ source and the dose influence the synthesis of the primary and secondary metabolites in various plant species. However, the literature is scarce in relation to the range of $\mathrm{N}$ concentration required to enhance the accumulation of phenolics in blueberry. In the present work, the concentration of phenolics in leaves of Legacy and Bluegold was reduced with an increase in $\mathrm{N}$ supplies (Figure 5A, 6). It appears that leaf $\mathrm{N}$ concentration of $15 \mathrm{~g} \mathrm{~N} \mathrm{~kg}^{-1} \mathrm{DW}$ could represent a critical threshold of $\mathrm{N}$ above which the synthesis of phenolics (mainly anthocyanins) decrease in blueberry leaves. Probably, above this critical leaf N concentration, $\mathrm{N}$ might be mainly shunted into amino acid and protein synthesis, and the formation of secondary compounds is decreased because the absence of $\mathrm{N}$ stress as supported by the lowest lipid peroxidation here observed (Figure 3A). This fact also suggest that at a $\mathrm{N}$ concentration below $15 \mathrm{~g} \mathrm{~N} \mathrm{~kg}^{-1}$, DW both cultivars allocated $\mathrm{C}$ resources to the formation of secondary compounds. These findings agree with the Bryant et al. (1983) hypothesis of carbon/nutrient balance (CNB), claiming that plants growing under $\mathrm{N}$ deficiency have more secondary metabolites than those in an $\mathrm{N}$-optimal environment.

Regarding the antioxidant enzyme SOD, which is widely recognized as the first line of defense against ROS (Alscher et al., 2002), it was activated significantly in Legacy at $0 \mathrm{mM} \mathrm{N}$ (Figure 7A). Accordingly, the lack of $\mathrm{N}$ in culture media triggered the enzyme activity to combat ROS production caused by $\mathrm{N}$ stress (Alscher et al., 2002). This may be also related to the maintenance of $\mathrm{CO}_{2}$ assimilation observed there (Figure 2), which is in line with previ- ous results for mulberry plants (Tewari et al., 2007). This enzymatic antioxidant mechanism seems to be important in Legacy for counteract the damage by $\mathrm{N}$ deprivation. On the contrary, in the case of Bluegold leaves, SOD activity showed the same tendency to increase, but at the highest $\mathrm{N}$ level (Figure 7A,C), which was associated with a substantial reduction in phenol concentration (Figure 5A). These findings might be related to compensatory antioxidant mechanisms aimed to maintain a steady ROS balance, as demonstrated by the low oxidative damage of membranes at the highest N supply (Figure 3A).

Our study revealed differential responses to $\mathrm{N}$ supply between blueberry cultivars, particularly under $\mathrm{N}$ starvation. Despite these differences, in order to preserve elevated antioxidant capacity in leaves, a threshold of about $15 \mathrm{~g} \mathrm{~N} \mathrm{~kg}^{-1} \mathrm{DW}$ for both cultivars can be recommended. Thus, it is important to highlight that a high antioxidant concentration in leaves may be deliver to fruits. Further studies are required to elucidate the mechanism explaining the relationship between tissue $\mathrm{N}$ concentration and the regulation of the plant antioxidant system at the molecular level in blueberry plants.

\section{Acknowledgments}

To FONDECYT project 1110726 for financial support. E. Yañez-Mansilla was supported by $\mathrm{PhD} \mathrm{CON-}$ ICYT Scholarship Chile and the Office of Research, Universidad de La Frontera.

\section{References}

Agüera, E., Cabello, P., De La Haba, P. 2010. Induction of leaf senescence by low nitrogen nutrition in sunflower (Helianthus annuus) plants. Physiol Plant.138, 256-67. 
Alscher, R.G., Erturk, N., Heath, L.S. 2002. Role of superoxide dismutases (SODs) in controlling oxidative stress in plants. J. Exp. Bot. 53, 1331-1341.

Asada, K., Takahashi, M. 1987. Production and scavenging of active oxygen in photosynthesis, In: D.J. Kyle, C.J. Arntzen, Eds. Photoinhibition: Topics in Photosynthesis, Elsevier, Amsterdam, pp: 227-287.

Bañados, M., Strik, B.C., Bryla, D.B. 2012. Response of highbush blueberry to nitrogen fertilizer during field establishment, I: accumulation and allocation of fertilizer nitrogen and biomass. Hort. Sci. 47, 648-655.

Bradford, M.M. 1976. A rapid and sensitive method for the quantification of microgram quantities of protein utilizing the principle of protein-dye binding. Anal Biochem. 72, 248-254.

Bryant, J.P., Chapin, F.S., Klein, D.R. 1983. Carbon/ nutrient balance of boreal plants in relation to vertebrate herbivory. Oikos. 40, 357-368.

Chang, C.C., Yang, M.H., Wen, H.M., Chern, J.C, 2002. Estimation of total flavonoid content in propolis by two complementary colorimetric methods. J. Food Drug Anal. 10, 178-182.

Cheng, G.W., Breen, P.J. 1991. Activity of phenylalanine ammonia-lyase (PAL) and concentrations of anthocyanins and phenolics in developing strawberry fruit. J. Am. Soc. Hort. Sci. 116, 865-869.

Chinnici, F., Bendini, A.A., Gaiani, A., Riponi, C. 2004. Radical scavenging activities of peels and pulps from cv. Golden delicious apples as related to their phenolic composition. J. Agric. Food Chem. 52, 4684-4689.

Diekmann, F., Fischbeck, G. 2005. Differences in wheat cultivar response to nitrogen supply II: differences in N-metabolism-related traits. J. Agron Crop Sci. 191, 362-376.

Donahue, J.L., Okpodu, C.M., Cramer, C.L., Grabau, E.A., Aslcher, R.G. 1997. Responses of antioxi- dant to paraquat in pea leaves, Relationships to resistance. Plant Physiol. 113, 249-247.

Du, Z., Bramlage, W.J. 1992. Modified thiobarbituric acid assay for measuring lipid peroxidation in sugar rich plant tissue extracts. J. Agric. Food Chem. 40, 1566-1570.

Ehlenfeldt, M.K., Prior, R.L. 2001. Oxygen radical absorbance capacity (ORAC) and phenolic and anthocyanin Concentrations in fruit and leaf Tissues of Highbush Blueberry. J Agric Food Chem. 49, 2222-2227.

Fritz, C., Palacios-Rojas, N., Feil, R., Stitt, M. 2006. Regulation of secondary metabolism by the carbon-nitrogen status in tobacco: nitrate inhibits large sectors of phenylpropanoid metabolism. Plant J. 46, 533-548.

Giannopolitis, C.N., Ries, S.K. 1977. Superoxide dismutases-occurrence in higher plants. Plant Physiol. 59, 309-314.

Hachiya, T., Watanabe, C.K., Fujimoto, M., Ishikawa, T., Takahara, K., Kawai-Yamada, M., Uchimiya, H., Uesono, Y., Terashima, I., Noguchi, K. 2012. Nitrate addition alleviates ammonium toxicity without lessening ammonium accumulation, organic acid depletion and inorganic cation depletion in Arabidopsis thaliana shoots. Plant Cell Physiol. 53, 577-91.

Hanson, E.J. 2006. Nitrogen fertilization of highbush blueberry. Acta Hort. 715, 347-351.

Hoagland, D.R., Arnon, D.I. 1950. The water culture method for growing plants without soil. Calif Agric Exp. Sta. Circular. 347, 1-32.

Huang, Z.A., Jiang, D.A., Yang, Y., Sun, J.W., Jin, S.H. 2004. Effects of nitrogen deficiency on gas exchange, chlorophyll fluorescence and antioxidant enzymes in leaves of rice plants. Photosynthetica. 42, 357-364.

Kováčik, J., Klejdus, B., Backor, M., Repcak, M. 2007. Phenylalanine ammonia-lyase activity and 
phenolic compounds accumulation in nitrogendeficient Matricaria chamomilla leaf rosettes, Plant Sci. 2, 393-399.

Larbat, R., Le Bot, J., Bourgaud, F., Robin, C., Adamowicz, S. 2012. Organ-specific responses of tomato growth and phenolic metabolism to nitrate limitation. Plant Biol. 1, 34-44.

Li, J., Zhu, Z., Gerendás, J. 2008. Effects of nitrogen and sulfur on total phenolics and antioxidant activity in two genotypes of leaf mustard, J. Plant Nutr. 31, 1642-1655.

Logan, B., Demmig-Adams, B., Rosenstiel, T., Adams, W. 1999. Effect of nitrogen limitation on foliar antioxidants in relationship to other metabolic characteristics. Planta. 209, 213-220.

Marschner, H. 1986. Mineral nutrition of higher plants, Academic Press London, UK.

Mogren, L.M., Olsson, M.E., Gertsson, U.E. 2006. Quercetin content in field-cured onions (Allium cepa L.): effects of cultivar, lifting time, and nitrogen fertilizer level. J Agric Food Chem. 54, 6185-6191.

Nybakken, L., Selås, V., Ohlson, M. 2013. Increased growth and phenolic compounds in bilberry ( $\mathrm{Vac}$ cinium myrtillus L.) following forest clear-cutting. Scand. J. For. Res. 28, 319-330.

Okamoto, G., Onishi, H., Hirano, K. 2003. The effect of different fertilizer levels on anthocyanoplast development in berry skin of Pione grapevines ( $V$. vinifera $\mathrm{x}$ V. labrusca). Vitis. 42, 117-121.

Reyes-Díaz, M., Inostroza-Blancheteau, C., Millaleo, R., Cruces, E., Wulff-Zottele, C., Alberdi, M., Mora, M.L. 2010. Long-term aluminum exposure effects on physiological and biochemical features of Highbush Blueberry cultivars. J Am Soc Hort Sci. 135, 212-222.
Reyes-Díaz, M., Meriño-Gergichevich, C., Alarcón, E., Alberdi, M., Horst, W.J. 2011. Calcium sulfate ameliorates the effect of aluminum toxicity differentially in genotypes of highbush blueberry (Vaccinium corymbosum L.). J. Soil Sci. Plant Nutr. 11, 59-78.

Ribera, A.E., Reyes-Díaz, M., Alberdi, M., Zuñiga, G.E., Mora, M.L. 2010. Antioxidant compounds in skin and pulp of fruits change among genotypes and maturity stages in highbush blueberry (Vaccinium corymbosum L.) grown in Southern Chile. J. Soil Sci. Plant Nutr. 10, 509-536.

Rojas-Lillo, Y., Alberdi, M., Acevedo, P., InostrozaBlacheteau, C., Rengel, Z., Mora, M.L., ReyesDíaz, M. 2013. Manganese toxicity and UV-B radiation differentially influence physiology and biochemistry of highbush blueberry (Vaccinium corymbosum L.) cultivars. Funct. Plant Biol. 41, 156-167.

Sadzawka, A., Grez, R., Mora, M.L., Saavedra, N., Carrasco, M.A., Flores, H., Rojas, C. 2004. Métodos de análisis de tejidos vegetales. Comisión de Normalización y Acreditación, Sociedad Chilena de la Ciencia del Suelo, Editorial Salesianos Impresores, Santiago, p. 113.

Slinkard, K., Singleton, V.A. 1977. Total phenol analysis: automation and comparison with manual methods, Am J Enol Vitic. 28, 29-55.

Tewari, R.K., Kumar, P., Tewari, N., Srivastava, S., Sharma, P.N. 2007. Macronutrient deficiencies and differential antioxidant responses-influence on the activity and expression of superoxide dismutase in maize. Plant Sci. 166, 687-694.

Yañez-Mansilla, E., Cartes, P., Reyes-Díaz, M., Ribera-Fonseca, A.E., Rengel, Z., Alberdi, M. 2014. Photosynthetic and antioxidant performance are differentially affected by nitrogen supply in highbush blueberry cultivars at the short-term, Cien. Inv. Agr. 41, 61-70. 